$\begin{aligned} & \text { Cold feet } \\ & \text { Greens revolt over } \\ & \text { German fusion } \\ & \text { research } \\ & p 107\end{aligned}$
1

\title{
South Africa turns to research in the hope of settling AIDS policy...
}

\section{Pretoria}

The relationship between HIV and AIDS is set to be put to the test in South Africa in a bid to defuse the controversy surrounding comments made by President Thabo Mbeki. He has often stated that he maintains an open mind on whether HIV is the cause of AIDS (see Nature 404, 911; 2000).

The inaugural meeting of an international panel, set up by Mbeki to advise on South African AIDS policy, announced the proposals last weekend. South Africa's Medical Research Council (MRC) will team up with the Centres for Disease Control (CDC) in Atlanta, Georgia, together with two prominent AIDS 'dissidents', who dispute that HIV causes AIDS, to devise a series of surveys to investigate the relationship between the disease and the virus.

According to MRC president Malegapuru Makgoba, the surveys could involve the clinical identification of a sample of AIDS sufferers, who would be tested for HIV. Another possibility is an epidemiological study correlating HIV-positive children with the HIV status of their parents.

A task force made up of Makgoba, Helene Gayle of the CDC - which has placed its database at the team's disposal - and two prominent dissidents, Berkeley biochemist Peter Duesberg and biotechnologist Harvey Bialy, has been appointed to conceptualize exactly what research needs to be done. Makgoba told Nature that the establishment of a national register for HIV/AIDS in South Africa - in which the CDC could presumably assist - is also on the cards.

Khotso Mokhele, president of the National Research Foundation and one of three facilitators on the international panel, said after the meeting that funding would be sought from the South African government and other bodies once the agenda had been clarified. He emphasized that existing knowledge, based on completed studies, should provide the basis for any new work.

In opening the two-day meeting, Mbeki emphasized the high level of heterosexual AIDS transmission in South Africa. He referred to the first South African paper on AIDS, published in 1985, which predicted

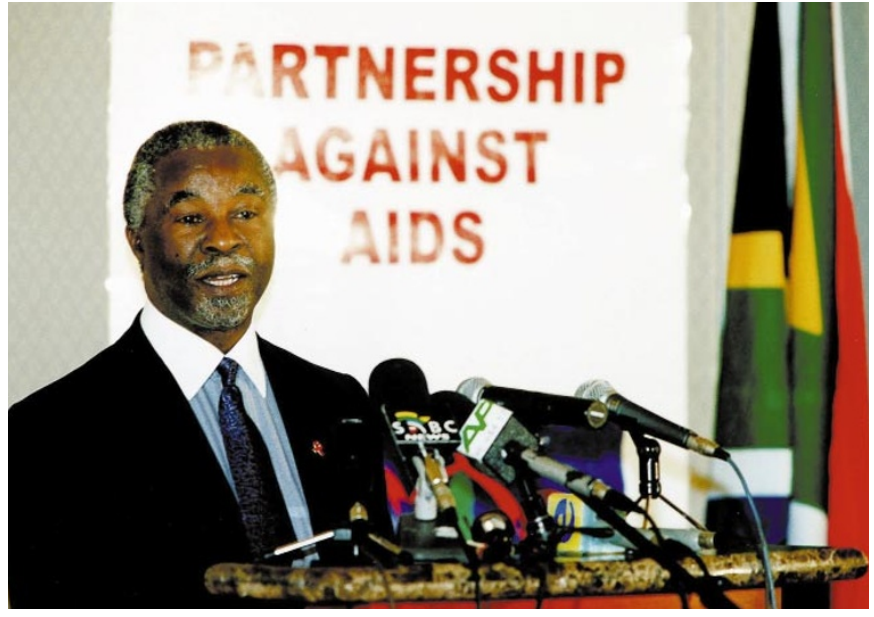

Shifting position? Mbeki is showing signs of having second thoughts about his 'open-minded' stance on the link between HIV and AIDS.

that the disease would remain largely confined to male homosexuals. The panel's task would be to try to explain why this situation had not changed in the West, but had in South Africa, he said, adding that the conclusions would have a direct bearing on the government's response to the problem.

But the composition of the 36-member panel is itself controversial, as just under half of its members are dissidents. "The panel has pretty well everyone on it who believes that HIV is not the cause of AIDS, and about 0.0001 per cent of those who oppose this view," comments AIDS researcher John Moore of Weill Cornell Medical College.

Announcing the panel last week, health minister Manto Tshabalala-Msimang said that it would consider the causes of the immune deficiency leading to AIDS, and the best response to the pandemic in a local con-

\section{...as editor defends publishing key AZT paper}

\section{London}

A peer-reviewed paper at the centre of the South African row over the efficacy of the anti-AIDS drug AZT was published as much to stimulate debate as to endorse its conclusions, according to the editor of the journal in which it appeared.

The paper, "A Critical Analysis of the Pharmacology of AZT and its Use in Aids", was published last year as a supplement to Current Medical Research and Opinion. Many of the paper's main authors are identified with the 'dissident' research community that claims that HIV is not the cause of AIDS.

South African president Thabo Mbeki has referred to this paper, which he came across on the Internet, in support of his reluctance to endorse the use of AZT — for example, to prevent the transmission of HIV from pregnant mothers to their babies.

But Peter Clarke, the journal's managing editor - who at the time was also in charge of editorial decisions - describes the paper as "more of a review rather than the result of original research per se". The paper was refereed over an "extended period of time" and views "varied widely", says Clarke.

"I felt that what the authors were trying to do - that is, critically appraise existing published material - was legitimate and deserved an opportunity to be made public." Clarke adds that he took many months to reach a decision: "At the end of the day I took the value judgement that it needed to go into the public domain to be debated." Natasha Loder http://www.librapharm.co.uk/cmro 
- text. It would also investigate why HIV/AIDS was heterosexually transmitted in southern Africa, and assess drug-based responses, including strategies to prevent mother-tochild transmission, she said.

Panel members include the French discoverer of the AIDS virus, Luc Montagnier, and Clifford Lane of the US National Institutes of Health. Twelve of the panel are USbased, and ten are African, including seven South Africans and representatives from Uganda, Malawi and Senegal. There are also members from Cuba, Mexico and India.

Significantly, with the exception of Sam Mhlongo of the Medical University of South Africa, none of the African representatives belong to the dissident camp. But several prominent South African AIDS researchers, all of whom have been outspokenly critical of the dissident movement, were not included. These include Jerry Coovadia of Natal University (convenor of the World AIDS Congress to be held in Durban in July), James McIntyre of the University of the Witwatersrand, immunologist Johnny Sachs, Gary Maartens of the University of Cape Town, and epidemiologist Bryan Williams of the Council for Scientific and Industrial Research.

"Although it's very important to determine innovative strategies for combating AIDS, engaging with fringe groups is not the way forward," says Glenda Gray, director of

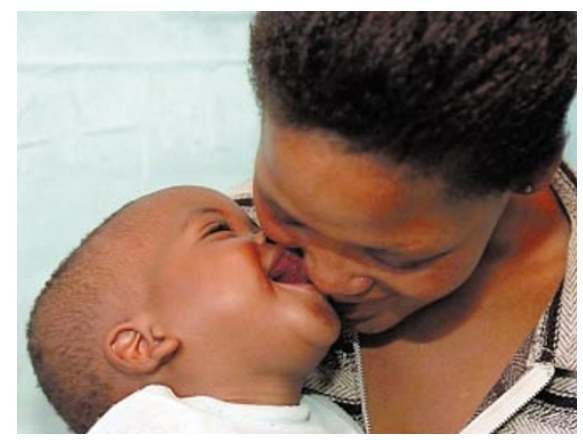

Parents and their children could be HIV-tested.

the perinatal HIV research unit at Johannesburg's Baragwanath hospital, who was also excluded from the panel. "These people should never have been given a platform."

Although Tshabalala-Msimang described the meeting as a "wonderful experience", it is said to have been very acrimonious, with the dissidents finding themselves in a minority in each of three groups appointed to discuss the causes, prevention and treatment of AIDS.

Instead of a final round-table discussion, the meeting is understood to have divided into groups representing the orthodox and dissident views.

The panel's chief facilitator, lawyer Stephen Owen of the Institute for Dispute Resolution at the University of Victoria in Canada, said at the press conference follow- ing the meeting that reaching consensus had not been the objective. "Divergent points of view remain, in very stark terms," he said.

The panel will enter into a "closed Internet debate" over the next four to six weeks, before reconvening in South Africa for a four-day discussion before the start of the World AIDS Congress on 9 July.

The task force is widely interpreted as a face-saving device for Mbeki, who admitted at the meeting's opening that he was "embarrassed to say" that he had "discovered that there had been a controversy about this for some time". Quoting the Irish poet Patrick Henry Pearse, Mbeki pondered whether his having raised the issue was "folly or grace".

There has been some speculation that a last-minute deal to add three extra nondissident members to the panel - thereby creating an overall majority of non-dissidents - was brokered at a high level between the South African and US governments.

The three additional names had not appeared on the initial list announced last week; neither Tshabalala-Msimang nor Essop Pahad, cabinet minister in the President's office, were prepared to confirm this at the press conference.

Some South African AIDS researchers feel that if the proposed surveys counter the claims of the dissident movement, they will have done a useful service.

\section{French research minister targets IT and biotech}

\section{Paris}

France's new research minister, Roger-

Gérard Schwartzenberg, promised last week that the government will substantially increase its support for research in information technology and biotechnology.

Schwartzenberg says that over four years he will double the research budget of France's computing research agency, INRIA, which received FF408 million (US\$56 million) in state support in 1998. In addition, a computer science division will be created at the Centre National de la Recherche Scientifique.

Schwartzenberg plans to use the research ministry's own funds to pay for these increases. He says that the money allocated for new technologies from the National Science Funds and the Funds for Technology Research, which the ministry directs, will increase by 50 per cent next year.

The budget increases were announced by Schwartzenberg during his first public speech on his plans for the post. He was appointed to head the research ministry in March after his predecessor, Claude Allègre, was sacked by the prime minister, Lionel Jospin, in a cabinet reshuffle.

Unlike Allègre, who ran a superministry overseeing higher education and research, Schwartzenberg will "have all of his time to dedicate to raising the research budget", says Vincent Courtillot, who served as research director under Allègre and will retain a similar position in the new ministry.

One priority highlighted by Schwartzenberg last week is to boost spending for life-sciences research. He also plans to set aside FF200 million as seed money for biotechnology companies, as well as a national network of 'incubators' specialized in raising biotech start-ups.

On most fronts, Schwartzenberg will continue with the policies of his predecessor. But he has broken with Allègre's opposition to building a new synchrotron facility on French soil (see Nature 404, 533; 2000). The new minister, while continuing a partnership with the British government and the Wellcome Trust to build the synchrotron Diamond in Britain at the Rutherford Appleton Laboratory near Oxford, is also pursuing a third-generation machine in France.

Last week Schwartzenberg met with British science minister Lord Sainsbury and discussed the possibility of British cooperation in the French project, Soleil. A

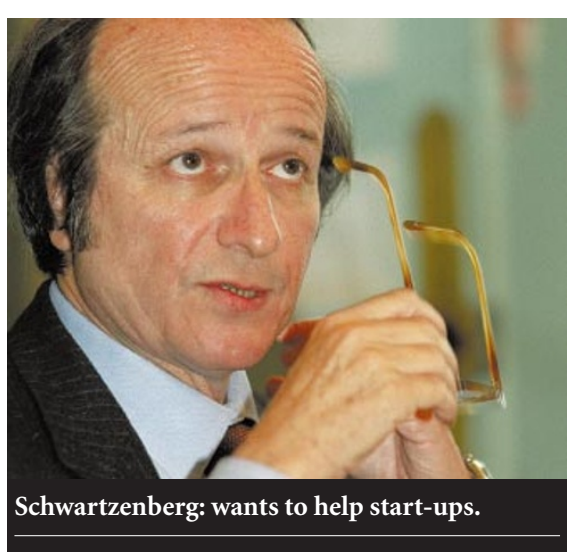

statement issued after the meeting said that the two facilities "would enable the scientific community in the future to cover a wide range of applications of synchrotron radiation".

Schwartzenberg's appointment coincides with France assuming the presidency of the European Union in July. In last week's presentation, he said he favoured accelerating the creation of a European patent, creating incubators and seed money for new technology companies, and harmonizing the tax system to favour the creation of new companies. Heather McCabe 